\title{
On Investigation Of Academic Discourse
}

\author{
Hamidova Nigar Shirkhan Gizi \\ Odlar Yurdu University
}

\begin{abstract}
The article deals with the investigations of academic discourse. The definition of discourse and text, as well as the explanation of academic discourse, research questions, and the comparison about the stated problem are presented in the article. The author presents her attitude toward various definitions of academic discourse. For instance, cited by A.Weidman and R.Patterson the academic discourse is analyzed like this: "Academic discourse, which is historically grounded, includes all lingual activities associated with academia, the output of research being perhaps the most important. The typicality of academic discourse is derived from the unique distinction making activity which is associated with the analytical or logical mode of experience (Weideman 2006, p.81-101). The scientists consider academic discourse to be more than grammar. It is the kind of discourse which has its functions such as exposition, clarification, and conclusion. Academic discourse requires the doers to perform things with language like explanation, definition, comparison, contrast, classification, agreement, disagreement, illustration, elaboration, making claims, seeing implications, inference, exemplifying, anticipating, and conclusion. The article states that this kind of discourse has also its cognitive and analytical processing. The competence is considered to be handling academic language is far more the "skills" of listening, speaking, reading, and writing. Academic discourse encourages the participants to do something about low levels of academic literacy, and in this case a participant should be able to measure that ability accurately and reliably. It is because of that academic discourse is a complex ability which encompasses many subcomponents; a language test that is multifaceted is preferable to a monotone test design and is likely to be more reliable. It is necessary to mention that language courses can be applied to improve academic literacy (Weidman 2014, p.13-22). The three theories such as the speech act theory by Austin and Searle, the frame theory by Goffman and Tannen and the politeness theory by Brown and Levinson have been touched upon in the article as well.
\end{abstract}

Key words: text, academic discourse, speech act, language, lesson, classroom

\section{INTRODUCTION}

If someone wants to understand the concept of academic discourse first of all it is necessary to understand the meaning of "discourse" and "text". There exist different opinions about the meanings of the two terms.

According to the "Linguistic Encyclopedia" complied by F.Y.Veysalli discourse is meant to be speech. F.Y.Veyselli claims that discourse is hyperbole which is usually observed in oral speech more than in writing. (Veysalli 2006, p.207).

According to "Washington State Library" discourse introduces interchangeable communication skills through discussion or conversation in everyday speech or writing.

The followers of F.de Saussure (Bally Sh. and Barthes R.) used the term "discourse" instead of the term "parole". In the usage discourse is considered to have wider sense than speech. The 
social tendency of F.de Saussure confirmed the social content of the term "discourse" (Barthes 1970, p.580-587).

It is noteworthy to mention that there are different approaches of the investigation of the term "discourse" in linguistic sources. As it is known in the linguistics the very term was firstly used by Z.Harris in his famous article "Discourse Analysis" (Harris 1956, p.1-30). In his article Z.Harris mentioned discourse being a larger unit than a sentence. Later M.A.K.Halliday, R.Wagner and others identify discourse and text. In those years the term "discourse" was widely mentioned in English sources. In the sources of German and Russian the term text was used instead.

In those periods both terms were used to express the unity of sentences and the conditions of distinguishing text and discourse. One of the main reasons differentiating the terms is that text has its formal and semantic features, and there is completeness between the sentences that form a text. The semantic completeness of a text is necessary for a person taking part in the mental processes. It proves that a text has its pragmatic content too.

On the other hand, text can also be observed outside the environment that surrounds the people. For example, the ancient manuscripts can illustrate this point of view. Some scientists don't have the same opinion about this point though. Text should have pragmatic effect. This approach is observed in the works of the scientists of 1980s years, and it leads to a new tendency as the attitudes of the relationship of text and discourse. There observed new and various approaches basing on the usage of discourse too. The quotation by N.E.Enkvist can be given as an example. He writes: "Discourse is the sum of context carrying the components of text and situation" (Enkvist 1989, p.369-382.)

This definition makes us think that discourse cannot exist without text and context. Some scientists are interested in the investigation of text through linguistic and psycholinguistic frame. Dressler 1970, de Beaugrande 1981, Moskolskaya 1981, Galpern 1981, Chernochovskaya 1983, Abdullayev 1998 and others carried out linguistic researches illustrating this problem.

According to J.Lyons a text is a sequence of sentences. As it stands, this is clearly - if "sentence" means, as it must be in this context, "text-sentence". It is true that there are some texts that would satisfy the definition, notably texts of a more formal character. J.Lyons states that the large numbers of everyday speech texts are formed from the mixture of sentences. These sentences are considered to be sentence-fragments and made-made locutions. It is necessary to mention that the defect in the definition of 'text' that has just been given is only one aspect of a more serious deficiency. It means its failure to make explicit the fact that the units of which a text is composed, if they are sentences or not. These sentences are not simply bonded together in sequence, but they must be connected in some contextually appropriate way. The text as a whole must exhibit the related, but distinguishable, properties of cohesion and coherence. (Lyons 1995, p. 262)

According to G.Brown and G.Yule text is the verbal record of a communicative event. Some scientists gave much tighter and more formal account of how English speakers' identify a text as forming a text. For example, the scientist such as van Dijk 1972, Gutwinski 1976, de Beaugrande and Dressler 1980, Halliday and Hassan 1976 investigated the term text from this point of view. They concerned with the principles of connectivity that connect a text together and force co-interpretation. Halliday and Hassan consider the set of sentences primary determinant, and they think that they do not constitute a text that depends on cohesive 
relationships within and between the sentences. These sentences create texture. Brown and Yule write: "A text has texture and this is not a text .... The texture is provided by the cohesive relation (Brown 1976, p.190). They consider cohesive relation within a text set up sentences where the interpretation of some element in the discourse is dependent on that of another. In this case they presuppose one another in the sense that it cannot be effectively decoded except by recourse to it (Brown 1976, p.190).

Halliday and Hassan outline taxonomy of types of cohesive relationships which can be formally established within a text, providing cohesive ties which connect the sentences inside the text together (Halliday 1971, p.191).

\section{SCOPE OF STUDY}

As it has been stated, the problem of discourse has been investigated widely from the beginning of the XIX century. The types of discourse such as political, economic, literary, military and others have been investigated comprehensively. The problem of discourse has been investigated not only in foreign countries but also in our native country too. Investigations show that a type of discourse 'academic discourse' which is observed in education centers such as at schools, universities has not been investigated thoroughly up today. This type of discourse is generally seen in the communication of teachers, lectures, pupils, students, etc. Though the problem has been observed in the researches of the scientists of Europe and America it hasn't been touched detailed. The mentioned problem has not been investigated by the Azerbaijani linguists either well.

\section{DISCUSSION}

The structure of academic discourse is commonly seen in the works of school psychologists A.Weidman and R.Patterson (Weideman 2014, p.13-22). The scientists claim that academic discourse is not only the sum of theory. It is the bind of the theory and the practice. It has its exposition, clarity, and conslusion. The explanation, comparison, opposition, agreement, disagreement, complain, reference, description, approval, disapproval etc. can be seen between the addresser and addresant while using academic discourse.

L.Backman and A.Palmer consider 'academic discourse' the type of conversation between teachers and students at schools and universities (Backman 1996, p.36). J.M.Swales suggests paying attention not to oral type but the written type of academic discourse (Swales 1969, p.29). H.D.Adamson has some other point of view about this problem. His opinion is that academic discourse covers academic competence. Academic competence used by H.D.Adamson means a combination of knowledge and competence, or ability. Adamson also stresses the importance of lower and higher levels of academician (Adamson 1993, p.47). According to him, the lower level is observed in the surface proficiency. The lower level is used in sending simple facts. The higher level is used to show cognitive ability. The cognitive ability in this level analyzes the relationship of parts to a whole. The higher level synthesizes and evaluates or judges the validity of argument. According to our point of view academic discourse can cover not only these two characters (i.e. knowledge and ability) but also the upbringing which bases on individuals' genes.

D.Ferris suggests critical thinking skills in academic discourse. He claims that classifying, comparing, analyazing, deducting, solving, questioning, critiquing, being skeptical and drawing conclusion can introduce critical thinking skills in academic discourse (Ferris 1998, p.289315). P.Elbow suggests four characters of academic writing. He lines them in such a way: 1. A 
version of reality that values explicitness and straightforward organization; 2. A way of talking to each other that excludes ordinary people; 3. A note of insecurity or anxiety imbued with cautiousness; 4. An element of display or a tendency to show off. It is important to underline that these features should not be carried over to spoken discourse; though the term academic discourse needs to be clarified more widely (Elbow 1995, p.72-83).

S.Watanabe elaborates the interaction basing on Tannen's theory (Watanabe 1990). In his theory Tannen accepts the theories of Goffman and Baterson. Tannen prefers the term 'agonism' in academic discourse (Tannen 1993, p. 101). In academic discourse 'agonism' means 'ritual adversativeness'. In her work Tannen underlines adversativeness. It generates criticing other's works. Tannen suggests negative consequences such as an assumption that critical dialogue is seen as negative critique. Consequently, academic dicourse is proved to be an agonistic verbal interaction. Some suggestions are given by Tannen to reduce agonism. McCormick and Kuhn express their point of view like this: 'critical thinking' is considered to be 'a group of builders constructiong a buiding' instead of 'a boxing match with that of a barnraising' (Kuhn 1984).

Academic discourse is usually observed in the teaching process, so it can balance the levels of communication. It covers the formation of dialogues among teachers and students. It also helps to choose language used among teachers and students. It is necessary to stress that the type of conversation which is observed between the teachers and students bases on high knowlege and ability.

It is necessary to underline that academic discourse is not the type of conversation that is easily gained. It is not the learned, but the taught factor of the language. This factor is proved to be the type of communication that can be created depending on the relationship of teachers and students cooperated. How they say: 'needle and thread' together. If any of these is missing, it is impossible to sew anything. For observing the academic discourse in the auditorium, it is necessary to form communication among teachers and students.

The components of academic discourse can be lined during the lessons as follows:

1. The teacher propeses the probelm, observes the student's answer, or accepts his/her answer;

2. The teacher stresses the importance of choosing the correct vocalulary. For instance, it is necessary to pay much attention to the usage of modal verbs if a teacher teaches modal verbs. The students should use more modal verbs in their speech, writing, or in making situations, etc. in the lessons.

The importance of cultural factors should not be forgotten in academic discourse either. There should be some behavioral differences among foreign students and native ones. It is because of the mental facts, and teachers ought to be more attentive on this. Some think that this process should not only be followed during the lesson process but also inside the education building. The following situation can clarify what is meant. For instance, the behaviour of the barmaid shouldn't be the same with the native students and the student from Japan. That is why we think that academic discourse should not be treated only in the auditorium but in the educational building as well. In this case the recruitment is also needed to be treated importantly. The workers in the educational centers should be chosen following the rules of academic discourse in some way. They say: 'Every fish can swim in its sea better.'

The role of cognition should not be forgotten in the realization of academic discourse. Cognition also plays an important role in formating the communication among teachers and 
students. The interactive interest among teachers and student, their interactive respect, communication, knowledge and competence must serve in thier purposes. A.Rosenberg claim the importance of cognition in academic discourse. D.Tannen writes: "Teachers need to form correct communication condition for forming relative relations among teachers and students" (Tannen 1984, p.112). H.Z.Waring suggests using rethorics in the communication of teachers and students (Waring 2000).

While analysing academic discourse strategies three theories are needed to be paid much attention. They are the theories of speech act theory, frame theory and politess theory.

Speech act theory introduces the smallest unit of lingustic communication. This kind of communication has its meaning or means of someting (Searle 1969,p.69). Because of this speech act is generally observed in oral discourse; it examines and analyzes. J.Austin used the term 'speech act' referring to an utterance and 'total situation in which utterance is made' (Austin 1962, p.98). M.Geis desctibes speech as: If 'speech act' means referring to the total situation rather than the minimal unit varies criticisms (Geis 1995, p.66). According to him it is because one of the criticism is from the perspective that speech act as a minimal unit that cannot function to make utterances perform actions. J.Thomas highlights the terms (used by J.Austin firstly) such as speech act, illocutionary act, illocutionary force. He also mentions the term 'pragmatic force'. The pragmatic force is just the force that is used interchangably. But illocutionary act as it is mentioned above is the one used by Austin (Austin 1962, p. 90). J.Austin categorized three acts. The first one is the locutionary act. It is the act that utterances with a certain sense and reference; The second one is the illocutionary act. It is the utterance with some sort of effect on the addressee. The third one is the perlocutionary act. It introduces the utterance producing certain consequential effects on a real action.

According to the investigations of J.Austin it is known that the term speech act refers to the function of utterance into act. That is why the locutionary act and speech act prove to be contradictory. Speech act theory causes the train of pragmatics, though the locutionary act cannot be regarded like this, as they lack the ability of communication. To sum up, locutionary act cannot cause any effect on the addresse, so clear verbal interactions cannnot be carried out. Though Thomas does not accept Austin's performative hypothesis. She (Tannen) claims that the concept of the performative verbs that Austin called for verbs performing action cannot be used for showing actions and even an absence of performatives may well bring about actions. It is clear to distinguish that Austin formed the cores of pragmatics by stating clear what is said and what is meant.

It is important to stress that the students of J.Austin such as Searle and Grice developed speech act theory into more systematical and specific frameworks respectfully. For instance, Searle suggeted indirect speech acts and eight different speech acts. Requesting, apologizing and others can be given as examples. Felicity condition that any speech act may end was deleloped by Searle as well. The other student of Austin Grice explicated a series of maxims (Grice 1975, p.41-58). He also analyzed the notion of implicature. Some drawbacks of speech act theory and dynamic speech act theory was also suggested M.Geis (Geis 1995, p.36). He (Geis) used the word 'dynamic' as he claimed that the static theory of speech act was made dynamic through carrying situatedness. The situatedness brought about approaches the proffered by conversation analysts and social factors through politeness theory. 
Frame theory is used practically for analyzing the micro construction of each segments of discourse. G.Bateson (Bateson 1972, p.57) introduced the notion of frame. He developed frame and explains it the way in which people exchange signals and agree with the intention of their messages. Goffman analyzed this concept as socially constructed nature of reality in the interpersonal relations. Two categories in the use of 'frame' was introduced by Tannen et al (Tannen 1993, p.12). The two categories introduced by the scientists are considered to be interactive frames of interpretation and knowledge structures, namely schemas. According to Tannen et al (Tannen 1993, p.57) the first refers to what is going on in interaction, the second one includes the concept of 'footing'. It is necessary to mention that the second category was developed by Goffman (Goffman 1969, p.15). Knowledge schema which introduces the second category refers to participants' expectations about what is going on the world. Interactive frames and knowledge schemas are used to interact with each other and implement the analysis of academic verbal exchanges in the study. J.Gumpers (Gumpers 1982, p. 111) used the term 'contextualization inference and cue'. According to him this term refers to the surface form of utterances indicating to be functional in the sygnaling of interpretative frames. While working the frame theory, the notion of contextualization inference and cues functions as an important apparatus for discourse analysis, revealing the features determining the academic discourse.

Conversation Analysts possess some approaches such as turn-taking system or preference organization. These are the approaches that are closely related to this theory. Some Conversation Analysts such as Schegloff do not accept this system. He denies to include background information that interlocutors carry (Goffman 1969, p.25). It is noteworthy to highlight that the term Conversation Analysis (CA) was derived from ethnomethodology and sociology mainly by Goffman (Schegloff 1974, p.696-735).

P.Brown and S.Levinson developed the politeness theory. Their theory was based on Goffman's analysis of ritual elements in social interaction that introduces the notion of 'face' (Brown 1987, p.67). The term 'face' was derived from Chinese meaning a self-concept projected by others. The fact was firstly used by Goffman (Goffman 1967, p.36). The aspects of face as basic wants, composed of negative and positive faces. These kinds of faces are used to show acts threatening positive or negative face, which is called 'face-threatening act' (FTA). The theory of politeness focusing on FTA was devised by Brown and Levinson. This theory introduces three variables effectively. The variables are power, social distance and imposition. In academic discourse that might include the concept of 'agonism' which is defined as 'ritualized advertiveness' by Tannen (Tannen 2002, p.1651-1669). According to Tannen it is plausible to employ this theory related to an FTA. Some socio-cultural consideration involving the social identity including gender, power relations arranged with interpersonal distance in oral academic discourse may have to be included. Imposition which is the other variable is still situated, and it depends on the context in discussion. This kind of variable seems to be dynamically related to other two variables. The other two variables such as power and socialdistance are not always static.

\section{METHODS}

The segments of verbal interchange can be led in micro-level and macro level. The communication is constructed by both speakers and hearers. Through the analysis of the way in which they exchange verbaly represents 'being academic', the elements charactering 'being academic' are formed. Speech acts such as disagreement, persuasion, assertion and others are used in the process of the micro-analysis. In addition, the analysis of collocation can be added for pedagogical applications. 
According to transcription convention given by Tannen we can create the following dialogue:

1. Teacher: what kind of morpheme is this?

2. Students: zero morpheme=

3. Teacher:=zero morpheme (.). Well, this is the way how we can distinguish the zero morpheme. (.)

It doesn't depend on us whether to use the zero morpheme or not. It is one of the ways how we form the words. $=$

4. Student: Is it important to care about [it.

5. Teacher: It is important. The explanation means that zero morpheme (or a null morpheme) is a morpheme that is realized by a phonologically null affix (an empty string of phonological segments). In simpler terms, a null morpheme is an "invisible" affix. It is also called a zero morpheme; the process of adding a null morpheme is called null affixation, null derivation or zero derivation.

The speech act of the utterance (1) is induction because the teacher induces the student involvement, calling for the attention from the student. The teacher asks and by this utterance he changes the frame of asking into giving some information about the mentioned fact, and so on. The student is aware of the answer, but he is not so much interested in the problem. The teacher has a power as well as obligation, or interest of asking, and giving the extra information about the question he gave. Though the student is not so much interested in the questioning, but he/she also prefers the teacher's insistance. It satisfies the student. This verbal exchange makes us have a feeling that the given question by the teacher was taken too simple for some of the students, but the teacher seemed to make sure whether the students are equipped with a basis of statistics and listened to his lecture. In respond of the students' answering the question, the teacher latches on the students' utterance. This matching may be interpreted as an affirmative feedback or agreement. Pomerantz suggests that no pause might show assessment of agreement (Pomerantz 1984, p.46). Regarding the organization of turntaking system the tern is much shorter than the terns taken by the teacher (Sack 1974, p.100). By latching one the students' utterance at the turn the teacher controls the size of students' turn at the transition relevance place, as well as showing the assessment of agreement. The turns (1) (2) and (3) construct the sequence of I (initiation) - R (response) - F (feedback) typical of classroom verbal interaction as suggested by Sinclair et al (Sinclair 1982, p.100).

\section{CONCLUSION}

The participants of the academic discourse might be/must be graduate students and their professors at schools and universities. The students aim is mastering English as a second language and for this purpose they do their best. The aim of the teacher can be observed in their knowledge, teaching ability, behaviors, etc. For studying English at school and universities students attend universities, schools or other education centres. In the buildings where they study they communicate through academic discourse. Academic discourse is observed among teachers and their students in their communication, and this discourse is mainly way of communication. It is based on the methods of observation, description, and analyses.

According to the above mentioned facts basing on academic discourse it becomes clear that verbal and extraverbal linguistic elements can often be seen in academic discourse. The linguistic environment of academic discourse is observed in the theories such as in speech acts, frame theory and politeness theory. The extralinguistic element is generally observed in teachers and students communication at schools, universities, and so on. Investigations show 
that the participants of academic discourse interact and mediate each other and negotiate in a dynamic way. Analysing each theoretical framework, the minute interaction should be explained, or paid much attention as well.

The non-native students of English in an academic community may behave appropriately according to their mental process, cognitive point of view, knowledge, ability, and gender. These facts should be paid much attention in academic discourse.

\section{References}

Adamson H.D. (1993). Academic Competence: Theory and classroom practice: Preparing ESL students for content courses. New York and London: Longman University Press.

Austin J. (1962). How to do things with words. Cambridge, MA: Harvard University Press.

Barthes R. (1970). La Linguistique du discourse - In: Sign, Language, Culture. The Hague-Paris, pp.580-587.

Brown G. and Yule G. (1983). Discourse Analysis. United Kingdom: Cambridge University Press.

Backman L. and Plamer A. (1996). Language Testing in Practice. Oxford: oxford University Press.

Bateson G. (1972). Steps to an ecology of mind. New York: Ballantine.

Brown P. and Levinson S. (1987). Politeness: Some universals in language usage. Cambridge: Cambridge University Press.

Enkvist N.E. (1989). From text to Interpretability: A Contribution to the Discussion of Basic Terms in Text linguistics. Connexity and Coherence: Analysis of Text and Discourse. Ed. By W.Heydrich. Berlin, New York: Mouton de Gruyter, pp.369-382.

Elbow P. (1995). "Being a Writer vs. Being an Academic: A Conflict in Goals." College Composition and Communication 46, pp.72-83.

Ferris D. (1998). Students' views of academic aural/oral skills: A comparative needs analysis. TESOL Quarterly, 32 (2), pp.289-315.

Goffman E. (1986). Frame analysis. New York: Harper and Row.

Goffman E. (1969). Interaction ritual. New York: Anchor Books.

Gumpers J. (1982). Discourse Strategies. Cambridge: Cambridge University Press.

Geis L.M. (1995). Speech acts and conversation interaction. Cambridge: Cambridge University Press.

Grice H.P. (1975). Logic and conversation. In Cole and Morgan (Eds.), Syntax and Semantics 3: Speech acts (pp.4158). New York: Academic Press.

Garfinkel H. (1969). Studies in ethnomethology. Englewood Cliffs, NJ: Prentice Hall.

Harris Z. (1956). Discourse Analysis. In: “Language”, 28, pp.1-30.

Halliday M.A.K. and Hassan R. (1971). Linguistic Function and Literary Style: An Inquiry into the language of William Golding's “The Ingeritors". "Literary Style: A Symposium”. Ed.Seymour Chatman, London-New York: Oxford University Press, pp.330-368.

Kuhn M.S. (1984). A discourse analysis of discussion in the college classroom. Unpublished doctoral dissertation. Harvard University. (UMI No.84211215).

Lyons J. (1995). Linguistic Semantics: An Introduction. United Kingdom: Cambridge University Press.

Pomerantz A.(1984). Agreeing and disagreeing with assessments: Some features of preferred/disprefered turn shapes. In M.Atkinson and J.Heritage (Eds.), Structures of social action, pp.57-101. Cambridge: Cambridge University Press.

Swales J.M. (1969). Genre analysis: English in academic and research settings. Cambridge: Cambridge University Press.

Searle J. (1969). Speech acts. Cambridge: Cambridge University Press.

Sack K., Schegloff E.A., and Jefferson G. (1974). A simplest systematics for the organization of turn-taking in conversation. Language, 50, pp.696-735. 
Sinclair J., Brazil D. (1982). Teacher Talk. Oxford: OUP.

Tannen D. (Eds.) (1993). Framing in discourse. Oxford-Oxford University Press.

Tannen D. (1984). Conversational style: Analyzing talk among friends. Nowwood, NJ: Ablex.

Tannen D. (2002). Agonism in academic discourse. Journal of Pragmatics 34, pp.1651-1669.

Veyselli.F.Y. (2006). Linguistic Encyclopedia. I Volume. Baku: Mutarjim.

Watanabe S. (1990). Framing in American and Japanese group discussions. Unpublished doctoral dissertation. George town University, Washington D.C. (UMI No 414199).

Waring H.Z. (2000). Discourse strategies used in seminar discussion: A conversation analytic approach. Unpublished doctoral dissertation, Teachers College, Columbia University, New York: Columbia University Press. (UNI No.9976768).

Weideman, A. (2006). Assessing academic literacy in a task-based approach. Language matters 37(1):81-101. Columbia University, New York: Columbia University Press.

Weideman, A. (2014). Innovation and reciprocity in applied linguistics. Forthcoming in Literator 35(1). Available DOI: Columbia University, New York: Columbia University Press http://dx.doi.org/10.4102/lit.v35i1.1074. 